\title{
IN VITRO CYTOTOXICITY ACTIVITY OF HYDROALCOHOLIC EXTRACT OF POLYHERBAL CHURNAM (COFRI) IN NORMAL LIVER AND KIDNEY CELL LINES
}

\author{
YASMINE Y, CAROLINE JEBA R* \\ Department of Biotechnology, Dr. M.G.R. Educational and Research Institute, Maduravoyal, Chennai - 600095, Tamil Nadu, India. \\ Email: janeshjeba@gmail.com
}

Received: 28 April 2018, Revised and Accepted: 12 December 2018

\begin{abstract}
Objective: The objective of the study was to investigate the cytotoxic activity of hydroalcoholic extract of a polyherbal powder on Vero (normal kidney) and Chang (normal liver) cell lines.

Methods: The cytotoxic effect was evaluated by 3-(4,5-dimethyl-2-thiazolyl)-2,5-diphenyl-tetrazolium bromide assay. It is commonly used colorimetric assay for assessing cell metabolic activity under specific conditions, indicates the number of viable cells.

Results: According to the experimental results, the hydroalcoholic extract does not cause any toxicity on normal liver and kidney cell lines and LC ${ }_{50}$ values are ca lculated using LDP line software and found $776.73 \mu \mathrm{g} / \mathrm{ml}$ and $686.58 \mu \mathrm{g} / \mathrm{ml}$.

Conclusion: The hydroalcoholic extract of polyherbal churnam exhibited cell viability at higher concentrations. The results indicates investigated formulation does not causes any toxicity to the normal liver and kidney cells and found to be safe for human consumption. Further, toxicological and pharmacological evaluation is required to prove its safety and efficacy.
\end{abstract}

Keywords: Polyherbal churnam, Cofri, 3-(4,5-dimethyl-2-thiazolyl)-2,5-diphenyl-tetrazolium bromide assay, Vero and Chang cell line.

(C) 2019 The Authors. Published by Innovare Academic Sciences Pvt Ltd. This is an open access article under the CC BY license (http://creativecommons. org/licenses/by/4. 0/) DOI: http://dx.doi.org/10.22159/ajpcr.2019.v12i3.26971

\section{INTRODUCTION}

Herbal products are of interest to many patients and health-care practitioners because more than $70 \%$ of the world's population is rely on herbal medicines for part of their primary health-care system. Herbal drug plays key role in management of various diseases especially cough and respiratory disease. Currently polyherbal formulations are employed for various types of diseases, such as cancer, diabetes and cough [1]. Cough is a common problem that everyone often faces. Cough is a natural reflex expulsive defence mechanism of the body, for clearing excess secretion or mucous or inhaled irritants or toxins or foreign substance in respiratory tract [2].

Cofri is a polyherbal Ayurvedic churnam, formulated as cough suppressant. The formulation is manufactured by a GMP certified manufacturing unit Rumi herbals Pvt., Ltd., Chennai. The ingredients used in the formulation were set to posses pharmacological activity such as antioxidant, anti-inflammatory, cough and cold, bronchial asthma, expectorant, and other certain respiratory disorders [3]. Poly herbal formulation has been used since ancient days to treat wide range of human diseases. The spices included in the Ayurvedic churnam are have strong medicinal properties of their own [4].

The use of this cell line as a model for normal human liver provide an acceptable model to explore general cellular cytotoxicity, as many of the known drug-induced cytotoxic mechanism, including inhibition of mitochondrial function, disruption of intracellular calcium homeostasis, activation of apoptosis, oxidative stress, and inhibition of specific enzymes and transporters and formation of reactive metabolites that cause direct toxicity is common to most cells [5]. Vero cell line derived from kidney of an African green monkey. It is one of the most common mammalian continuous cell line used in research. Vero cells are sensitive to infection with arboviruses, reoviruses, rubella, influenza viruses, and others [6].

Cytotoxicity studies with normal cell culture system of plant extract or medicinal plant extract have not been studied extensively and this is vital for the safety evaluation or any herbal preparations [7]. Thus, the need for toxicity tests to determine the safe dose for oral consumption. In the present study, an attempt has been made to study the cytotoxic activity of hydroalcoholic extract "Cofri" using normal cell lines such as Vero cell line and Chang liver cell line.

\section{METHODS}

Raw materials

All the required raw materials were procured from local vendors at Chennai region with the certificate of analysis and compared the quality as per the AYUSH guidelines.

\section{Formulation}

The dried parts of the raw materials were coarsely grinded, powdered, sieved and mixed by using double cone blender and further processed as per in hose standard operating procedure.

\section{Determination of physiochemical parameters}

The finished product was assessed for its quality using in-house quality control specifications maintained at DSIR approved Rumi Herbals R\&D Centre. Protocol for testing Ayurvedic, Siddha and Unani Medicines, Pharmacopoeia laboratory for Indian Medicine, and Government of India protocols was adopted for quality analysis of finished product [8].

Finished product specifications

a. Description: The parameters such as color, taste, and odor were assessed by sensory organs.

b. Total ash content: Incinerate about 2-3 g accurately weighed of the ground drug in a tarred platinum or silica dish at a temperature not exceeding $450^{\circ} \mathrm{C}$ until free from carbon, cool, and weigh. Collect the residue on an ashless filter paper, incinerate the residue and filter paper, add the filtrate, evaporate to dryness, and ignite at a temperature not exceeding $450^{\circ} \mathrm{C}$ weight noted.

c. Acid-insoluble ash: Boil the ash obtained in (total ash content) for $5 \mathrm{~min}$ with $25 \mathrm{ml}$ of dilute hydrochloric acid, collect the insoluble matter in a 
crucible, or on an ashless filter paper, wash with hot water and ignite to constant weight. Calculate the percentage of acid insoluble ash.

d. Water soluble ash: Proceed as directed for the determination of acid insoluble ash, using water instead of ethanol.

e. Loss on drying: Place $10 \mathrm{~g}$ of material after accurately weighing it in a tarred evaporating placed in Petri dish and dried at temperature $105^{\circ} \mathrm{C}$ for $5 \mathrm{~h}$, and weigh. Calculate the percentage of moisture content.

f. Alcohol extractive content: Macerate $5 \mathrm{~g}$ of the coarsely powdered drug, with $100 \mathrm{ml}$ of alcohol of the specified strength in a closed flask for $24 \mathrm{~h}$, shaking frequently during $6 \mathrm{~h}$ and allowing stand for $18 \mathrm{~h}$. Filter rapidly, taking precautions against loss of solvent, evaporate $25 \mathrm{ml}$ of the filtrate to dryness in a tarred flat-bottomed shallow dish, and dry at $105^{\circ} \mathrm{C}$, to constant weight and weigh. Calculate the percentage of alcohol-soluble extractive.

g. Water extractive content: Proceed as directed for the determination of alcohol extractive, using double-distilled water instead of ethanol.

h. Ether extractive content: Transfer a suitably weighed quantity of the air-dried, crushed drug to an extraction thimble, extract with solvent ether in a continuous extraction apparatus for $6 \mathrm{~h}$. Filter the extract quantitatively into a tarred evaporating dish and evaporate off the solvent on a water bath. Dry the residue at $105^{\circ} \mathrm{C}$ to constant weight. Calculate the percentage of ether extractive values.

i. $\quad \mathrm{pH}(5 \%$ solution at room temperature): $5 \mathrm{~g}$ of the coarse powder was dissolved in $100 \mathrm{ml}$ of water in a closed flask, shaking frequently during $6 \mathrm{~h}$ and allowing it to stand for $18 \mathrm{~h}$. It was filtered and filtrate was separated. The $\mathrm{pH}$ of the solution is determined using $\mathrm{pH}$ meter.

\section{Determination of cytotoxicity activity}

\section{Cell line and culture}

Vero and Chang cell line was obtained from National Centre for Cell Sciences, Pune. The cells were maintained in Dulbecco's modification of Eagle medium (DMEM) supplemented with $10 \%$ fetal bovine serum, penicillin $(100 \mu \mathrm{g} / \mathrm{ml})$, and streptomycin $(100 \mu \mathrm{g} / \mathrm{ml})$ in a humidified atmosphere of $50 \mu \mathrm{g} / \mathrm{ml} \mathrm{CO}_{2}$ at $37^{\circ} \mathrm{C}[9]$.

Screening of in vitro cytotoxic activity of hydroalcoholic extract of polyherbal churnam on Vero and Chang cell lines by 3-(4,5-dimethyl-2-thiazolyl)-2,5-diphenyl-tetrazolium bromide (MTT) assay

Two separate experiments were carried out using same protocol Mosmann, 1983. The procedure briefly, cells $\left(1 \times 10^{5} /\right.$ well $)$ were plated in 24-well plates and incubated in $37^{\circ} \mathrm{C}$ with $5 \% \mathrm{CO}_{2}$ condition. After the cell reaches the confluence, the various concentrations of the samples were added and incubated for $24 \mathrm{~h}$. After incubation, the sample was removed from the well and washed with phosphate-buffered saline (pH 7.4) or DMEM without serum. $100 \mu \mathrm{l} /$ well $(5 \mathrm{mg} / \mathrm{ml}$ ) of $0.5 \%$ MTT was added and incubated for $4 \mathrm{~h}$. After incubation, $1 \mathrm{ml}$ of DMSO was added in all the wells. The absorbance at $570 \mathrm{~nm}$ was measured with UV-spectrophotometer using DMSO as the blank. The percentage cell viability was calculated using the following formula: \% Cell viability $=A_{570}$ of treated cells $/ A_{570}$ of control cells $\times 100$. Measurements were performed and the lethal concentration required for $50 \%$ cell mortality $\left(\mathrm{LC}_{50}\right)$ was determined by LDP line software.

\section{RESULTS}

\section{Description}

The formulation was found light brown color soft granules, pungent taste and clove spicy odor.

\section{Physicochemical parameters}

a. Cytotoxicity effect of sample on Vero (normal kidney) cell lines

b. Cytotoxicity effect of sample on Chang (normal liver) cell lines.

\section{DISCUSSION}

Nowaday's, most of the world population showing interest to use of herbal preparation. Always there is an increasing demand for quality
Table 1: Physico-chemical parameters of finished product

\begin{tabular}{lll}
\hline S.No & Parameters & Results (\%) \\
\hline 1 & Total ash & 1.45 \\
2 & Acid-insoluble ash & 1.05 \\
3 & Water soluble ash & 0.25 \\
4 & Loss on drying & 2.2 \\
5 & Alcohol soluble extractive content & 22.72 \\
6 & Water-soluble extractive content & 64.16 \\
7 & Ether soluble extractive content & 0.40 \\
8 & pH at room temperature & 5.17 \\
\hline
\end{tabular}

Table 2: Cytotoxicity effect of various concentrations of hydro alcoholic extract of sample on Vero cell line

\begin{tabular}{llll}
\hline S. No & $\begin{array}{l}\text { Concentration } \\
(\boldsymbol{\mu g} / \mathbf{m l})\end{array}$ & $\begin{array}{l}\text { Absorbance } \\
(\mathbf{O D})\end{array}$ & $\begin{array}{l}\text { Cell } \\
\text { viability (\%) }\end{array}$ \\
\hline 1 & 7.8 & 0.676 & 97.82 \\
2 & 15.6 & 0.625 & 90.44 \\
3 & 31.2 & 0.578 & 83.64 \\
4 & 62.5 & 0.527 & 76.26 \\
5 & 125 & 0.479 & 69.31 \\
6 & 250 & 0.430 & 62.22 \\
7 & 500 & 0.385 & 55.71 \\
8 & 1000 & 0.336 & 48.62 \\
9 & Cell control & 0.691 & 100 \\
\hline
\end{tabular}

Table 3: Cytotoxicity effect of various concentrations of hydroalcoholic extract of sample on Chang cell line

\begin{tabular}{llcc}
\hline S. No & $\begin{array}{l}\text { Concentration } \\
(\boldsymbol{\mu g} / \mathbf{m l})\end{array}$ & $\begin{array}{c}\text { Absorbance } \\
\text { (OD) }\end{array}$ & $\begin{array}{c}\text { Cell } \\
\text { viability (\%) }\end{array}$ \\
\hline 1 & 7.8 & 0.778 & 99.48 \\
2 & 15.6 & 0.722 & 92.32 \\
3 & 31.2 & 0.670 & 85.67 \\
4 & 62.5 & 0.12 & 78.62 \\
5 & 125 & 0.556 & 71.09 \\
6 & 250 & 0.508 & 64.96 \\
7 & 500 & 0.452 & 57.80 \\
8 & 1000 & 0.395 & 50.51 \\
9 & Cell control & 0.782 & 100 \\
\hline
\end{tabular}

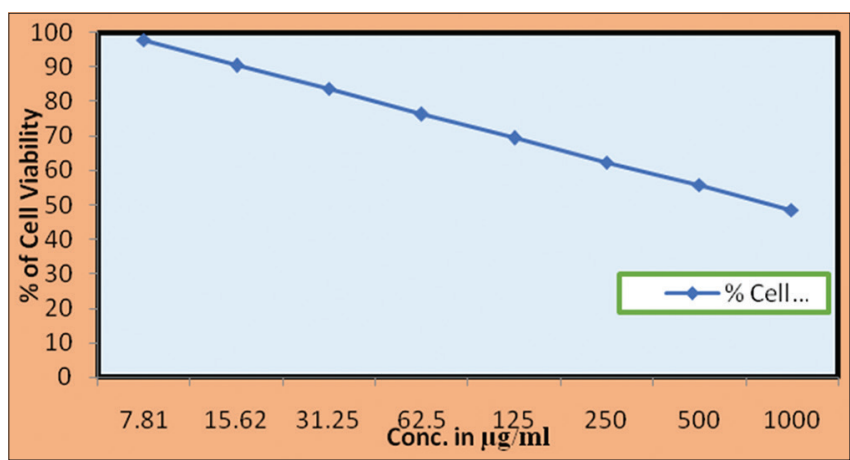

Fig. 1: Percentage of cell viability Vero cell lines after treating with different concentrations of hydroalcoholic extract of sample

herbal products. Scientific validation is another tool to ascertain quality and efficacy of specific product. In the present study, a polyherbal preparation is taken for assessing its quality and safety. As a primary task, some in vitro assays such as cell line models are used to assess its safety [10]. Other quality control parameters are assessed as per the guidelines prescribed by AYUSH.

The selected formulation contains total ash value is $1.45 \%$ which indicative of total amount of inorganic materials after complete 


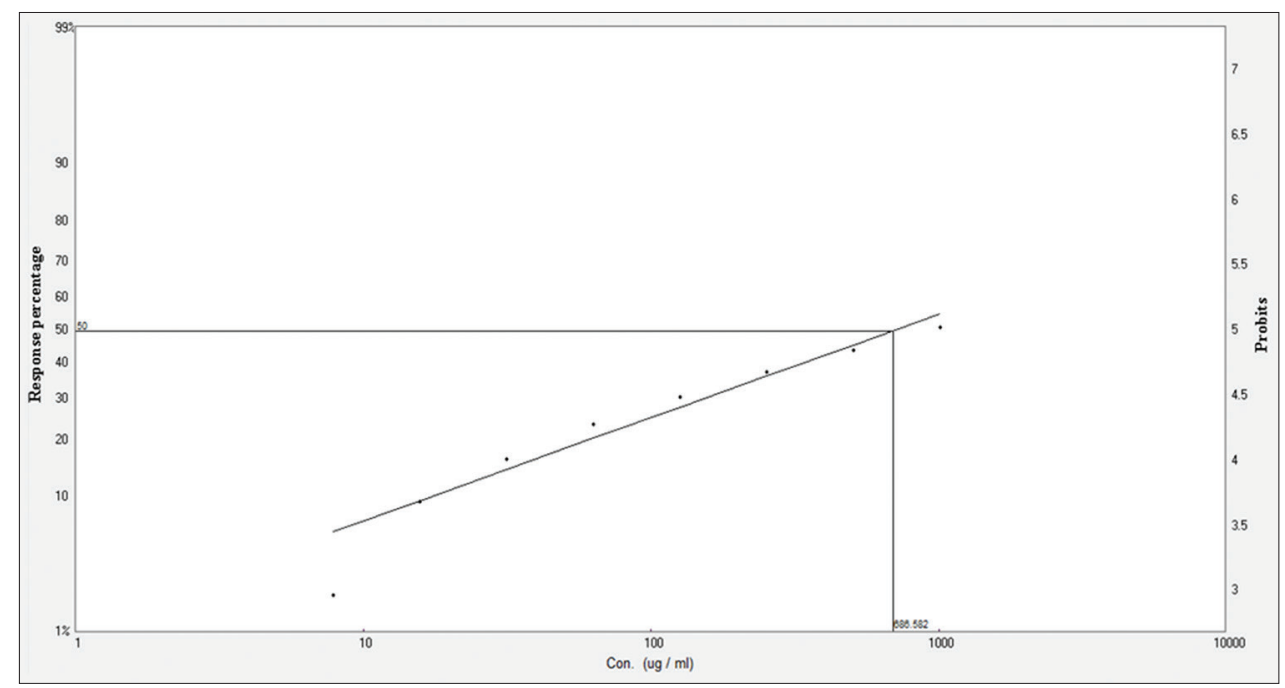

Fig. 2: Determination of $\mathrm{LC}_{50}$ of sample on Vero cell lines using LDP line software
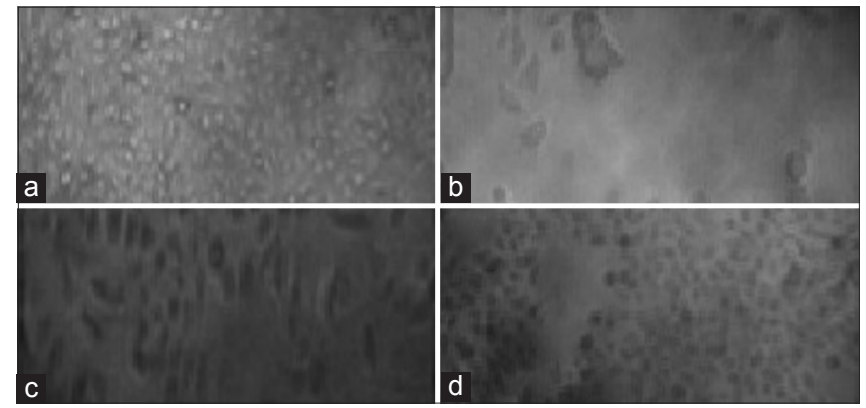

Fig. 3: Photomicrograph of Vero cell lines treated with different concentrations of hydroalcoholic extract of sample (a) normal Vero cell line, (b) toxicity at $1000 \mu \mathrm{g} / \mathrm{ml}$, (c) toxicity at $62.5 \mu \mathrm{g} / \mathrm{ml}$, (d) toxicity at $7.8 \mu \mathrm{g} / \mathrm{ml}$

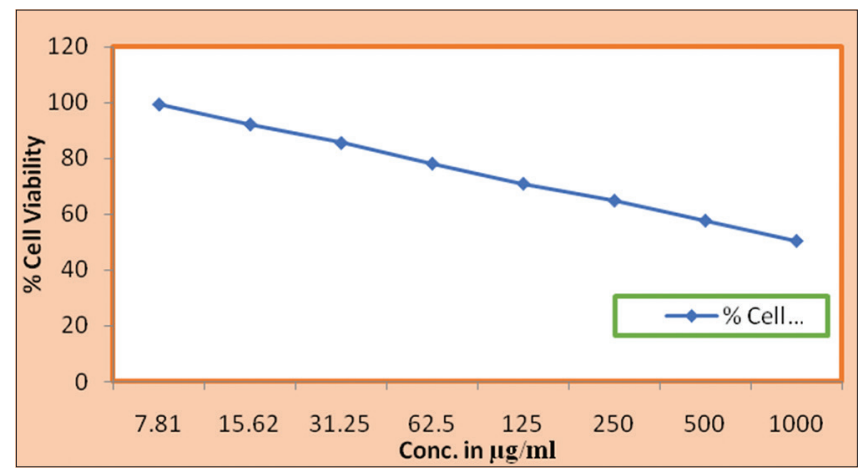

Fig. 4: Percentage of cell viability Chang cell lines after treating with different concentrations of hydroalcoholic extract of sample

Table 4: Lethal concentrations of hydroalcoholic extract of sample on Vero and Chang cell lines

\begin{tabular}{llll}
\hline S. No & $\begin{array}{l}\text { Lethal concentration } \\
(\boldsymbol{\mu g} / \mathbf{m l})\end{array}$ & $\begin{array}{l}\text { Vero cell } \\
\text { lines }-\mathbf{L C}(\boldsymbol{\mu g} / \mathbf{m l})\end{array}$ & $\begin{array}{l}\text { Chang cell } \\
\text { lines }-\mathbf{L C}(\boldsymbol{\mu g} / \mathbf{m l})\end{array}$ \\
\hline 1 & 50 & 686.58 & 776.73 \\
2 & 75 & $4,860.40$ & $4,985.63$ \\
3 & 90 & $28,295.50$ & $26,575.68$ \\
\hline
\end{tabular}

incineration. The acid insoluble ash value is indicative of silicate impurities and it contains only $1.05 \%$. Loss on drying is indicative of amount of moisture content present in the drug. As per the AYUSH guidelines, the moisture content should be $<5 \%$ and the formulation contains $2.2 \%$. If less moisture is present, there is less chances of microbial contamination as well as good shelf life. More water-soluble portion is present in sample that is $64.14 \%$ and $22.72 \%$ alcohol soluble content, $0.40 \%$ of ether-soluble content (Table 1). The ethanol extract of the leaves had high anticancer activity than the stem extract on both Vero and MCF-7 cell lines [11].

Cytotoxicity studies were conducted using normal liver (Chang cell lines) and normal kidney (Vero cell lines) because any drugs taken into the system will reach to liver where some metabolic transformations are takes place and eliminated through the kidney. These organs are the primary safety concern of any drug manufacturer. The Chang and Vero cell lines are commonly used to assess the cytotoxic effect before conducting experiments on animals. MTT assay was utilized widely to determine the viability of the cells. The in vitro experimental data will provide basic information about toxicity and dose selection. The Vero cell lines are exposed to different concentrations of hydroalcoholic extract of polyherbal sample and found $48.62 \%$ of cell viability at the highest concentration $1000 \mu \mathrm{g} / \mathrm{ml}$ (Table 2) and $\mathrm{LC}_{50}$ value found $686.58 \mu \mathrm{g} / \mathrm{ml}$ (Figs. 1 and 2). There is no much variation in the morphological characters of the treated cells and the results are shown in Fig. 3. At the same way, Chang liver cell lines are exposed to different concentrations of hydroalcoholic extract of polyherbal sample and found $50.51 \%$ cell viability at the concentration of $1000 \mu \mathrm{g} / \mathrm{ml}$ and $\mathrm{LC}_{50}$ value was $776.73 \mu \mathrm{g} / \mathrm{ml}$ (Tables 3 and 4, Figs. 4 and 5). A Fig. 6 show photomicrograph of Chang liver cell lines and does not found any significant variations compare to control cells. Polyherbal formulation also possess antispasmodic activity [12]

\section{CONCLUSION}

As per AYUSH guidelines, the polyherbal churnam was evaluated and results obtained were said to be within the mentioned limits. Cytotoxicity activity of the hydroalcoholic extract of polyherbal churnam on Vero and Chang normal cell lines also determines not have any notable cytotoxicity; hence, the polyherbal churnam can be consumed internally. It can be promoted effectively as cough suppressant if proved through pharmacological and clinical studies. The future work will be aimed to study toxicological profiling and in vivo antitussive activity of selected formulation.

\section{ACKNOWLEDGMENT}

The authors are thankful to Dr. R. Siva Siddharth, Director, Jayachandra Kuncha, Research Associate, Thirugnana Sambantham Head, Rumi Herbals R\&D Centre, and Dr. N. Narayanan, Mr. T. Kuppuswamy, 


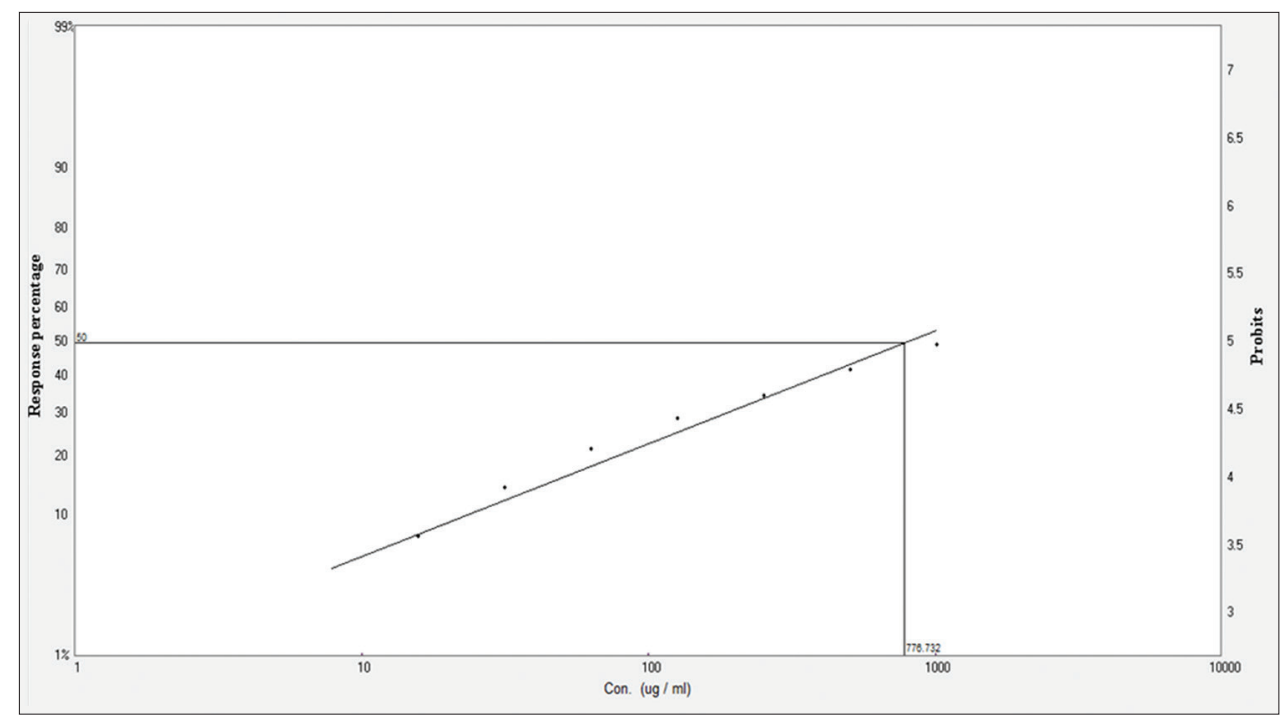

Fig. 5: Determination of $\mathrm{LC}_{50}$ of sample on Chang cell lines using LDP line software
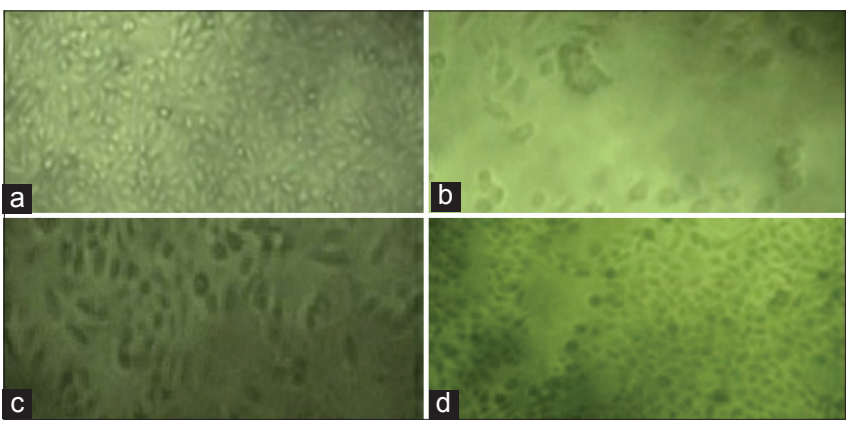

Fig. 6: Photomicrograph of Chang cell lines treated with different concentrations of hydroalcoholic extract of sample (a) normal Chang cell line (b) toxicity at $1000 \mu \mathrm{g} / \mathrm{ml}$ (c) toxicity at $125 \mu \mathrm{g} / \mathrm{ml}$ (d) toxicity at $7.8 \mu \mathrm{g} / \mathrm{ml}$

Scientists, Mr. S. Baskar, QC Chemist, Rumi Herbals Pvt., Ltd., Chennai, Tamil Nadu, India, for providing necessary facilities and technical support for the successful completion of the project. We confirmed that the manuscript has been read and approved by named authors and declared that this manuscript is original.

\section{REFERENCES}

1. Brik CS, Kanungo SK, Tripathy NK, Panda JR, Padhi M. A review on therapeutic potential of poly herbal formulation. Int J Pharm Sci Drug Res 2015;7:211-28.
2. Parihar M, Chouhan A, Harsholiya MS, Pathan JK, Banerjee S, Khan N, et al. A review-cough and treatments. Int J Nat Prod Res 2011:1:9-18.

3. Tewari D, Kumar M. Formulation and comparative evolution of different sitopaladi herbal syrups. Pharm Lett 2014;6:178-83.

4. Pattnayak P, Panda S, Dash S, Behera M, Mishra SK. Study of antitissuve activity of sitopaladichurna: A polyherbal formulation. Int $\mathbf{J}$ Pharm Sci Rev Res 2010;4:65-7.

5. Otang WM, Grierson DS, Ndip RN. Cytotoxicity of three South African medicinal plants using the chang liver cell line. Afr J Tradit Complement Altern Med 2014;11:324-9.

6. Senthilraja P, Kathirasan K. In vitro cytotoxic MTT assay in Vero, HepG2 and MCF-7 cell lines study of marine yeast. J Appl Pharm Sci 2015;5:80-4

7. Khushboo J, Dhara B, Maltreyl Z. In vitro cytotoxicity activity of some selected ethanomedicinal plants against Vero cell line. Int J Pharm Sci Rev Res 2016;37:130-3.

8. Lohar DR. Protocol for Testing Ayurvedic, Siddha and Unani Medicines. Kohima, Nagaland: Pharmacopoeial Laboratory for Indian Medicine. Ministry of AYUSH; Govt. of India.

9. Patel S, Gheewal N, Suthar A, Shah A. In vitro cytotoxicity activity of Solanum nigrum extract against Hela cell line and Vero cell line. J Pharm Pharm Sci 2009;41:38-46.

10. Sumalatha D, Nithya TG. In vitro antioxidant and anticancer activity of Murraya koenigii against human colon cancer HT-29 cell line. Asian J Pharm Clin Res 2013;7:83-6.

11. Nazeemabanu B, Julie J, Abirami J, Kumaresan R, Muthukumaran T, Rajasree S, et al. Anti-cancer activity of Datura metal on MCF-7 cell line. Asian J Pharm Clin Res 2014;7:181-3.

12. Saini N, Kamalsingh G. Pharmacological evaluation of a polyherbal formulation for its antispasmodic activity. Int $\mathrm{J}$ Green Pharm 2015;9:104-9 